\title{
Nová publikace k jubileu Evy Havlové
}

Bohumil Vykypěl - Vít Boček, eds.:

\section{Teorie a praxe české etymologické lexikografie.}

Praha: Nakladatelství Lidové noviny, 2020, 78 s.

ISBN: 978-80-7422-731-8

V červnu roku 2019 se v etymologickém oddělení Ústavu pro jazyk český AV ČR v Brně diskutovalo u kulatého stolu. Tématem byla Teorie a praxe české etymologické lexikografie - tentýž název nese i sborník, který z této akce vzešel. Stejně jako setkání i 24. svazek z tematické řady Studia Etymologica Brunensia představuje odkaz Evy Havlové - at' se jedná o vzpomínání na osobní, nebo odborné úrovni. Eva Havlová je autorkou mnoha odborných prací, z nichž je nutno připomenout zejména České názvy savců (2010) a disertační práci z roku 1964 Názvy pro věk a věčnost, vydanou knižně v r. 2017. Eva Havlová se také spolupodílela na vzniku důležitých kolektivních děl, např. na Všeslovanské slovní zásobě (KopečNÝ 1964) a Etymologickém slovníku jazyka staroslověnského. Samotný sborník obsahuje šest příspěvků; autory tří z nich jsou členové brněnského organizačního týmu (B. Vykypěl, V. Boček, I. Janyšková, H. Karlíková), další tř́i pak napsali lexikografové z Prahy (J. Rejzek), Bratislavy (L. Králik) a Halle (H. Bichlmeier).

Autor prvního př́spěvku Bohumil Vykypěl (Př́spěvek E. Havlové k teorii a praxi (nejen) etymologie, s. 9-12) popisuje E. Havlovou jako jazykovědkyni, která důsledně zakládala své teorie na praxi, „stavěla obecné principy na konkrétní zkušenosti“ (s. 9); napsala však i několik studií, které popisovaly etymologovu práci obecně. Hlavním okruhem jejího zájmu byl sémantický aspekt etymologické práce; zde bychom mohli vyzdvihnout naléhavou potřebu slovníku sémantických změn, kterou E. Havlová zmínila už v roce 1965 a která stále přetrvává i u současné generace jazykovědců. E. Havlové také vděčíme, jak zdůrazňuje B. Vykypěl, za rozhodující podíl na koncepci Etymologického slovníku jazyka staroslověnského (dále jen ESJS). Především díky ní má ESJS hutné a pečlivě hierarchizované etymologické výklady. Zavedla rovněž speciální oddíl expanze, důležité novum, které zachycuje vliv staroslověnštiny na ostatní jazyky. Díky materiálu shromážděnému v tomto heslovém oddílu se nabízí prostor pro další samostatné výzkumy.

Vít Boček (Poznámky k struktuře etymologického slovníku obecně a k věcně řazenému etymologickému slovníku zvláště, s. 13-21) se ve svém textu věnuje mikrostruktuře a makrostruktuře etymologických slovníků. Na začátku konstatuje, že teorie etymologické lexikografie není př́liš rozvíjeným oborem - dá se však vycházet z teorií ke slovníkům výkladovým a přehledovým, jež jsou součástí tzv. metalexikografie. Dále popisuje, jak jsou vymezovány struktura slovníku a typologie, které byly představeny v odborné literatuře. Zaměřuje se i na praxi a poznamenává, že lépe bývá ve slovnících popsána makrostruktura, tedy výběr lexika, jež je ve slovníku analyzováno, a pořadí heslových statí, než mikrostruktura, tedy stavba hesla a výběr informací, které jsou do heslových statí zahrnuty. Pozornost věnuje V. Boček též 
onomaziologickým etymologickým slovníkům. Uvádí a srovnává čtyři zahraniční práce ${ }^{1}$ které se obvykle považují za tento typ slovníků, jako tematicky řazené etymologické slovníky však tyto práce označit nelze. Autor zdůrazňuje, že věcně řazené slovníky, které by zpracovávaly celou slovní zásobu jednoho jazyka, chybí, byly by ale potřeba právě jako podklad a východisko pro sestavení slovníku sémantických změn.

Jiří Rejzek (K výběru lexika v etymologických slovnících, s. 23-26) ukazuje na př́ikladu svého slovníku (Český etymologický slovník, 2001², 2015²), jakým zpo̊sobem probíhala selekce heslových slov, jaký byl jeho postup a cíl. Vzhledem k tomu, že jeho slovník je zacílen na širší publikum, rozhodl se zpracovat výklad běžné slovní zásoby, a to včetně slov přejatých a nespisovných. Programově chtěl zařadit také běžné vulgarismy, aby prolomil tabu v české lingvistice. Přiznává, že při výběru slov se potýkal s nedostatkem zdrojů, často se tak řídil i svou intuicí. Je jasné, že výběr slov je do jisté míry vždy subjektivní - to se také ukázalo při recenzi prvního vydání, kterou napsala právě E. Havlová. Zdůraznila v ní mimo jiné, že nepoměrně velký prostor ve slovníku dostaly sportovní termíny, naopak nedostatečně jsou podle ní zastoupeny výrazy ze zoologické a botanické nomenklatury.

L'ubor Králik (Etymologický výskum slovenského jazyka: aktuálny stav, možnosti, perspektívy, s. 27-40) popisuje současný stav etymologického výzkumu slovenského jazyka. Jako předěl se ukazuje Králikův Stručný etymologický slovník slovenčiny, první etymologický slovník tohoto slovanského jazyka, který vyšel v roce 2015 a má populárně-vědecký charakter. Jak autor konstatuje, je potřeba dívat se dál, na další projekty - po populárně-vědeckém slovníku by měla následovat příprava většího vědeckého díla - takové, které by se neměly orientovat jen na aktuální slovní zásobu, ale i na předchozí období vývoje jazyka. To bohužel není nyní ve slovenské jazykovědě možné, organizačně ani personálně. Východisko se tedy našlo v etymologické databázi slovenského lexika - projekt bude dostupný online. Jeho realizaci zabezpečuje právě L'. Králik. Nejde cestou exhaustivního etymologického výkladu, jedná se spíše o systematizaci dosavadních poznatků slovanské etymologie ve vztahu k slovenskému jazyku, omezuje se totiž pouze na informaci o praslovanském etymologickém východisku, doplněnému soupisem odborné literatury k danému rekonstruovanému výrazu. Analogický je pak postup i při přejímkách. Důležité je, že se díky tomu mohou soustředit veškeré síly na výzkum lexikálních jednotek, ke kterým ještě neexistují etymologické hypotézy, a také na korekce již existujících etymologických výkladů.

Ilona Janyšková a Helena Karlíková (Odkaz Evy Havlové etymologickému oddělení, s. 41-49) představují E. Havlovou ve společném příspěvku nejen jako výjimečnou vědkyni, která byla uznávaná doma i ve světě, a př́snou školitelku, ale i jako laskavého a srdečného člověka v lidech sice mohla vzbuzovat dojem člověka uzavřeného sama do sebe, ale jak mimo jiné ukazuje její korespondence s ostatními lingvisty, měla velký zájem o svoje kolegy a jejich rodiny. V textu jsou rozsáhlé ukázky z dopisů např. s Emilií Bláhovou nebo Igorem Němcem. Dopisy jsou jako součást pozůstalosti E. Havlové uloženy v etymologickém oddělení ÚJČ.

1 Jedná se o slovník BuckŮV (1949), DELAMARRŮV (1984), SCHRÖPFERŮV (1979-1994) a o práci GAMKRELIDZEHO a IVANOVA (1984, 2: 465-831). 
V poslední studii (Das Etymologische Wörterbuch des Althochdeutschen als Vorbild für ein etymologisches Wörterbuch des Alttschechischen, s. 51-78) autor Harald Bichlmeier popisuje Etymologický slovník staré horní němčiny - proces jeho vzniku až do aktuálního 6. dílu a dalších připravovaných. První 4 svazky jsou digitalizovány a připraveny k publikování na internetu, zbylé díly se budou digitalizovat posléze. V další části $\mathrm{H}$. Bichlmeier popisuje materiálový základ pro Etymologický slovník staré horní němčiny včetně zdrojů a pramenů. Na praktických př́kladech ukazuje, jakým způsobem je pojata mikrostruktura hesla, jak jsou zpracovány přejímky, a popisuje strasti, se kterými se autoři slovníku museli při tvorbě tohoto díla vypořádat. V poslední části se pak Bichlmeier zaměřuje na svoje postřehy $\mathrm{k}$ možnému etymologickému slovníku staré češtiny (resp. jak sám říká, zaměřuje se na své „sny“ o možném etymologickém slovníku staré češtiny - s. 71). Popisuje dvě možné varianty - jednak maximalistickou, jednak střídmou. V té první mimo jiné zdůrazňuje, že by měl být v hesle zaznamenán původní tvar lexikální jednotky s citací v plné formě, u sloves také kmenové formy. Pokud by byl slovník online, dala by se jednoduše propojit heslová slova a skeny materiálů nebo alespoň referenčních pasáží. Pro čtenáře by také bylo přínosné, kdyby věděl, v jakém časovém období se dané slovo objevilo nejdříve - ideálně s přesností na 25 let. Zahrnutí dialektologického materiálu by bylo pro čtenáře žádoucí, avšak přináší jen poměrně malý přínos do etymologického výkladu - časově by takový výzkum byl velmi náročný. Na zvážení by

pak byla základní kontrola materiálu, aby se zjistilo, jestli dialekty neodráží např. odchylky, které by vedly k jiné společné slovanské rekonstrukci než staročeská a novočeská slova. Ideální by pak bylo zaznamenávat i různé vokalické změny např. v rámci kořene slov, ze kterých by se pak dala vyvodit původní slovanská intonace. Skromnější plán by zahrnoval postup jako u ESJS. Bichlmeier sám upozorňuje na to, že pro češtinu bohužel neexistují práce, ze kterých by se dalo vycházet, jako to je pro starou horní němčinu. Budoucnost tedy ukáže, jak bude nakonec etymologický slovník staré češtiny vypadat - jakékoliv zpracování materiálu by však bylo př́nosem.

Na závěr můžeme shrnout, že nevelký sborník, který na počest E. Havlové vznikl, je v mnohých směrech inspirací. Ukazuje pevný odborný základ, který E. Havlová pomohla vybudovat, a také otevírá nové obzory a nabízí témata pro další výzkum.

\section{LITERATURA}

Buck, Carl D. 1949. A Dictionary of Selected Synonyms in the Principal Indo-European Languages: A Contribution to the History of Ideas. Chicago: University of Chicago Press.

Delamarre, Xavier. 1984. Le vocabulaire indo-européen. Lexique étymologique thématique. Paris: Librairie de Amérique et d'Orient.

Gamkrelidze, Tamaz V. - Ivanov, Vjačeslav V. 1984. Indojevropejskijjazyki indojevropejcy, 1-2. Rekonstrukcija $i$ istoriko-tipologičeskij analiz prajazyka $i$ kul'tury. Tbilisi: Izdatel'stvo tbilisskogo univerziteta.

KARLÍkOvÁ, Helena. 1999. Soupis prací Evy Havlové. SPFFBU A 47, 189-193. 
VILlnow KomÁRKovÁ, Jana. 2009. Dodatek k soupisu prací Evy Havlové. Linguistica Brunensia 57 (1-2), 2009, 201-203.

KopečnÝ, František, ed. 1964. Základní všeslovanská slovní zásoba. Brno: Academia.

SCHRÖPFER, Johannes, ed. 1979-1994. Wörterbuch der vergleichenden Bezeich nungslehre. Onomasiologie, Band 1: Lieferung 1/2, 3/4, 5/6, 7/8, 9/10, Heidelberg: Heidelberg Winter.

Poděkování: Příspěvek vznikl na základě řešení projektu Čeština v jednotě synchronie a diachronie-2020 (MUNI/A/O913/2019).

\author{
Lucie Štěrbová \\ Czech Language Institute of the CAS, v. v. i. \\ Veveř́ 97, 602 oo Brno \\ Czech Republic \\ lucie.sterbova@ujc.cas.cz
}

